\title{
The Effectiveness of Project Based Learning and Discovery Learning with Modul to Improve Learning Outcome for AutoCAD Subject
}

\author{
Aufa Ashfahani ${ }^{\bowtie}$, Haryono Haryono, Kustiono Kustiono \\ Pascasarjana, Universitas Negeri Semarang, Indonesia
}

\begin{tabular}{l} 
Article Info \\
\hline History Articles \\
Received: \\
May 2020 \\
Accepted: \\
June 2020 \\
Published: \\
November 2020 \\
\hline Keywords: \\
AutoCAD, Discovery \\
Learning, Learning \\
Outcome, Project Based \\
Learning.
\end{tabular}

\begin{abstract}
In fact of AutoCAD learning, there is still the use of conventional method. So, the students does not achieve the quality maximally. It is important to make the innovation of learning model in order to produce the competent outcomes. This study aims to determine the effectiveness of Project Based Learning and Discovery Learning with module to increase learning outcome of AutoCAD subject. Those are three main parts of this study. The first is the different influence between Project Based Learning and Discovery Learning on the learning outcome, the second is the different influence between male and female on the learning outcomes and the third is the interaction between Project Based Learning, Discovery Learning and gender on the learning outcome. This research was $2 \times 2$ factorial experiment with a quantitative approach. The data source of this study were 186 students of class XI of SMKN (Vocational School) 4 Semarang in the 2019/2020 school year. From 186 students, there were 36 students of class XI TGB1 as the experimental class and 37 students of class XI TGB2 as the control class. The results shows that Project Based Learning model and Discovery Learning with module could improve students' learning outcomes in SMK 4 grade XI. From the gender interaction aspect of the Project Based Learning model and Discovery Learning, it shows the learning outcomes for male are higher than female. Thus, the Project Based Learning model is appropriate for AutoCAD subject because it can prepare students to face the workforce.
\end{abstract}

\footnotetext{
Correspondence address:

Pascasarjana, Universitas Negeri Semarang, Indonesia

Jalan Kelud Utara III, Semarang, Jawa Tengah, Indonesia

p-ISSN 2252-6404

e-ISSN 2502-4515

E-mail: aufaaufa@gmail.com
} 


\section{INTRODUCTION}

Education is one of foundations to educate the nation because the measurement of nation progress is through the level of public education (Slameto, 2010). One thing that is really crucial in education is its quality and learning outcomes (Raharjo, 2012). One component that could fight to improve students' learning outcome is a teacher (Biesta, 2017). In education, teacher is one indicator of the achievement of learning objectives. A teacher roles as a model, planner, forcaster, leader, and guide to the center of learning and the students role as the object of learning (Zein, 2016). In this case, the main focus in Indonesian educational system is the students' achievement with the life skill to handle their own walfare, family and people around them in the future (Shoimin, 2013:15). So that, it is very crucial to consider the quality of education for the improvement of the next generation and a teacher as the center of learning should be aware of this condition because teachers have responsibilities to improve the development of education.

Based on the preliminary observation with the AutoCAD teacher in SMK 4 class XI, it showed that the students' achievement for AutoCAD subject is still under the minimum criteria. The average score of their final test for female is 71,5 and for male is 74 . Beside the result of observation, Insany (2016) argued that the use of conventional learning method in the process of teaching and learning makes the students passive and gets low achievement. There are two factors influencing students' learning outcomes: 1) intern (from the students) like physical factors including psychology and tiredness, 2) extern (outside the students) like family, schools, and citizens or environment (Saputra, Ismet \& Andrizal, 2018). To sum up, the methods of learning in the process of teaching could influence students' achievemnts. It is also a must to make some innovation to fulfil the value of minimun criteria in the learning process.

Project Based Learning is a method using scientific approach. This approach guides the students to follow the process of inquiry and improve the quality of eduation (Sumarn, 2015). In the research of Susilowati, Iswari \& Sukaesih (2013), they said that Project Based Learning gives the positive influence on students' learning outcomes. In more detail, Haryudo \& Anggara (2016) said that Discovery Learning is appropriate to use in the process of teaching and learning and it is effective to improve students' achievemnt. Rosdiana, Boleng \& Susilo (2017) found that Discovery Learning has effectivity because the students give some positive responses to this method. According to Imawan (2015), Project Based Learning and Discovery Learning are effective to use because they could improve students' learning outcomes. Different from the previouse research, the method of learning used in AutoCAD subject especially at SMK 4 Semarang class XI is still the conventional method. It also causes the student to keep memorizing the material and as the result, they could not achieve the minimum criteria of the subject. Thus, educational prcaticioner should develope the new learning method which is suitable and appropriate for AutoCAD learning. One of the best way is developing Project Based Learning and Discovery Learning to achieve the expected minimum criteria that be useful for their job in the future.

\section{METHOD}

This research was $2 \times 2$ factorial experiment with a quantitative approach (Creswell, 2012). The population of the research was class XI of SMK 4 Semarang. The sampling technique was random sampling. Data collection techniques in this study were test and non-test. Test was in the form of 20 numbers of multiple choice questions to express the average value of students and non-test was in the form of documents to see the gender of each student.

The valid and reliable research instruments were also in the form of multiple choice questions and SPSS version 16 was used to get the validity and realiability test and also to analyze the level of difficulty and different 
power. Different power criteria can be seen in table 3.2. Data analysis technique in this research was descriptive data analysis.

\section{RESULTS AND DISCUSSION}

1. The Effect of Project Based Learning and Discovery Learning Models on Student Learning Outcomes
There is the different result between control class and experiment class; the mean value/average value of experiment class is 82,64 and control class is 67,64 . From this difference, it shows that the experimental class is more influential on students' learning outcomes in AutoCAD subjects. The calculation results of Project Based Learning Model and Discovery Learning with Module is in table 1.

Tabel 1. Calculation of Project Based Learning Model and Discovery learning with Module on Learning Outcomes

\begin{tabular}{|c|c|c|c|c|c|c|c|c|c|}
\hline \multicolumn{10}{|c|}{ Paired Samples Test } \\
\hline & & \multicolumn{5}{|c|}{ Paired Differences } & \multirow[b]{3}{*}{$t$} & \multirow[b]{3}{*}{$\mathrm{df}$} & \multirow[b]{3}{*}{ Sig. (2-tailed) } \\
\hline & & \multirow[b]{2}{*}{ Mean } & \multirow[b]{2}{*}{ Std. Deviation } & \multirow{2}{*}{$\begin{array}{l}\text { Std. Error } \\
\text { Mean }\end{array}$} & \multicolumn{2}{|c|}{$\begin{array}{l}95 \% \text { Confidence Interval of the } \\
\text { Difference }\end{array}$} & & & \\
\hline & & & & & Lower & Upper & & & \\
\hline Pair 1 & $\begin{array}{l}\text { Pretest eksperimen- } \\
\text { Posttest eksperimen }\end{array}$ & -26.562 & 10.035 & 1.774 & -30.181 & -22.944 & -14.973 & 31 & .000 \\
\hline Pair 2 & $\begin{array}{l}\text { Prestest Kontrol- } \\
\text { Posttest Kontrol }\end{array}$ & .33 .889 & 7.664 & 1.277 & .36 .482 & -31.296 & -26.532 & 35 & .000 \\
\hline
\end{tabular}

From the analysis, the result is 0,000 , which means that $0,000<0.05$. It also summerizes that the learning outcomes of AutoCAD by using Project Based Learning and Discovery Learning with modules have different effects on learning outcomes with an average value of $-26,562$ for Project Based Learning with module and 33,889 for Discovery Learning with module. So, it concludes that Project Based Learning with module is more influential than Discovery Learning learning on AutoCAD learning outcomes. This is in line with the theory of Imawan (2015) that Project Based Learning is more effective than Discovery Learning. Rose \& Prasetya (2014) also believed that Project Based Learning is effective to improve students' learning outcomes. The result of the research conducted by Moestofa and Sondang (2013) has the similarity which shows that the process of teaching and learning using Project Based Learning gives better result compared to the conventional method. According to Chiang \& Lee (2016), Project Based Learning is not only improving sudents' motivation in vocational school but also giving the ability to solve the problems. Setyawan \& Munoto (2016) said that Project Based Learning could improve students' learning outcomes and Saputra (2016) said that same ideas about this method. To sum up, Project Based Learning has and gives influence on students learning outcome for AutoCAD subject. it is also effective to use in the classroom because it helps students to achieve their learning indicators. In this process of learning, students are given the task to work on projects in the form of $2 \mathrm{D}$ building drawings and for the final test, students are asked to make a project in the form of some objects from 2D building drawings as an assessment for graduation. Through the application of this method, they could improve and develope their progress.

2. Different Effects between Male and Female on Learning Outcomes in AutoCAD Subjects with Module

The calculation of learning outcomes for AutoCAD subject with Project Based Learning and Discovery Learning models between male and female students, paired samples test, gets 0,000 results, which means $0,000<0.05$. It shows that AutoCAD learning outcomes using Project Based Learning and Discovery Learning models with modules have positive influence on male and female students. There are the differences in AutoCAD learning outcomes between male and female students. Male students gets the average of $-6,031$ and female 
gets the average of $-6,281$. So, based on these results, male students are superior to women. Calculation of the different influence between male and female students on learning outcomes in AutoCAD subjects with the help of modules can be seen in table 2 .

Table 2. Different Effects between Male and Female Students on Learning Outcomes in AutoCAD Subjects with Modules

\begin{tabular}{|c|c|c|c|c|c|c|c|c|c|}
\hline \multicolumn{10}{|c|}{ Paired Samples Test } \\
\hline & & \multicolumn{5}{|c|}{ Paired Differences } & \multirow[b]{3}{*}{$t$} & \multirow[b]{3}{*}{ df } & \multirow[b]{3}{*}{ Sia (2-tailed) } \\
\hline & & \multirow[b]{2}{*}{ Mean } & \multirow[b]{2}{*}{ Std Deviation } & \multirow{2}{*}{$\begin{array}{l}\text { Std. Error } \\
\text { Mean } \\
\end{array}$} & \multicolumn{2}{|c|}{$\begin{array}{l}95 \% \text { Confidence interval of the } \\
\text { Difference }\end{array}$} & & & \\
\hline & & & & & Lower & Usser & & & \\
\hline Pair 1 & $\begin{array}{l}\text { Perempuan- } \\
\text { Perempuan }\end{array}$ & -30.158 & 10.738 & 1.898 & -34.028 & -26.285 & -15.887 & 31 & .000 \\
\hline Pair 2 & Lak-laki- lakflako & -31.406 & 8.056 & 1.424 & -34311 & -28.502 & -22.054 & 31 & .000 \\
\hline
\end{tabular}

Based on the results of this study, it shows that the calculation of learning outcomes for AutoCAD subject with Project Based Learning and Discovery Learning models between male and female students gets the result of 0,000 . It means that $0,000<0.05$ It also concludes that learning outcomes using Project Based Learning and Discovery Learning learning models with modules have a positive influence on male and female students. From the power view, male students are superior to female students. The results of this study are in line with the opinion of Baron \& Byrne (2005) who said that male gender indirectly influences learning outcomes. According to Nafi'an (2011) men's reasoning is stronger than women's. Furhther, Syafitri (2017) said that the visual abilities of male students are better than female students. Apart from that, Afriana, Permanasari \& Fitriani (2016) also agreed with the results of this study that there are positive responses from male and female students to the application of Project Based Learning for STEM in air pollution learning but male students are superior to female students. Yuwono, Udiyono, Maárif \& Sulistiana (2019) also argued that the Project Based Learning model can improve students' learning outcomes but male students get better grades than female students. In the case of AutoCAD learning, it requires good reasoning because predicting a good and precise building design requires good visual skills as well as in the form of $2 \mathrm{D}$ and $3 \mathrm{D}$ building floor plans. So, male students are potentially more superior in this case and it is why that male students get better learning outcomes. To conclude, it can be stated that male students are superior to the learning outcomes for AutoCAD subject.

3. The Interaction Between Project Based Learning and Discovery Learning with Gender on Learning Outcomes in AutoCAD Subjects with Modules.

The last result is the average culculation of the interaction between project based learning and discovery learning with gender on learning outcomes in autocad subjects with modules. The result shows that there are differences between female and male students. The average value of female students is 75.47 while male students is 78.75. The details can be seen in table.

Table 3. Average Results for Female and Male Students

\begin{tabular}{|c|c|c|c|c|c|}
\hline & & \multicolumn{4}{|c|}{ Group Statistics } \\
\hline Class & & $\mathrm{N}$ & Mean & Std. Deviantion & Std. Error Mean \\
\hline Autocad Learning & Woman & 32 & 75.47 & 8.068 & 1.426 \\
\hline Outcomes & Man & 32 & 78.75 & 8.032 & 1.420 \\
\hline
\end{tabular}

Based on the results of the study, it shows the differences between female and male students. female students get the average of
75.47 and male students get the average of 78.75. This shows that the average value of male students is higher than female. The results of this 
study are in line with the opinion of Nafian (2011) who said that men are superior to women. Whereas Muslim (2017) also believesd that the Project Based Learning model increases more students' learning outcomes in men than in women. Sumianingrum, Wibawanto \& Haryono (2017) argued that gender influences the learning outcomes of male and female students. Romadloniyah \& Setiaji (2020) argued that the learning styles of male and female students differ significantly, where the visual style of men is better than women. Based on the results of the study and supported by the opinion of the researchers, it can be concluded that the Project Based Learning model is more effective in improving learning outcomes in male students because there are different achievements between male and female students. These differences can affect the aspects of students' learning outcomes experienced in AutoCAD learning at SMK 4 Semarang.

\section{CONCLUSION}

Based on the findings, the writer concludes that; 1) The learning model of Project Based Learning and Discovery Learning with module has some differences. Project Based Learning model has the average of 82.64 while Discovery Learning model has the average of 67.64 on the learning outcomes of SMK 4 grade XI students. 2). In terms of gender, based on the results of the study, it is obtained the differences between female students with an average of 75.47 and male students is 78.75. This shows that the average value of male students is higher than female in AutoCAD subject with module at SMK 4 Class XI. 3) Based on the interaction between Project Based Learning and Discovery Learning with Gender, it is concluded that male students interact more actively than female students in AutoCAD subjects learning and it can be seen from the average learning outcomes which is obtained by female students with an average of 75.47 while male students obtained the average of 78.75 .

\section{REFERENCES}

Afriana, J., Permanasari, A., \& Fitriani. (2016) Penerapan Project Based Learning Terintegrasi STEM untuk Meningkatkan Literasi Sains Siswa Ditinjau dari Gender. Jurnal Inovasi Pendidikan IPA, 2 (2), 2016, 202 -212 https://i ournal.uny.ac.id/index.php/iipi/article/view $18561 / 9022$

Anggara,T., R. \& Haryudo. I. S. (2016). Pengembangan Modul Pembelajaran Berbantuan Software AutoCAD pada Mata Pelajaran Instalasi Penerangan Listrik di SMK Negeri 1 Trenggalek. Jurnal Pendidikan Teknik Elektro, 5, 2, 499 - 506 https://iurnalmahasiswa.unesa.ac.id /index.php/iurnal-pendidikan-teknikelektro/article/view/14841.

Biesta G. (2017). Don't be fooled by ignorant schoolmasters: On the role of the teacher in emancipatory education. London: Policy Futures in Education.

Byrne, M., B. (2005) Factor Analytic Models: Viewing the Structure of an Assessment Instrument From Three Perspectives. Journal of Personality Assessment, 85, (1), 17-32 https://www.ncbi.nl m.nih.gov/pubmed/16083381

Chiang, L., C. \& Lee. H. (2016). The Effect of Project-Based Learning on Learning Motivation and Problem-Solving Ability of Vocational High School Students. International Journal of Information and Education Technology, .6(9), 709-71 http://www.ijiet.org/show-76881-1.html

Creswell, W. J. (2012). Research Design Pendekatan Kulitatif, Kuantitatif dan Mixed. Yogyakarta: Pustaka Pelajar.

Insany, S., A., Y. (2016) Pengaruh Model Pembelajaran Kooperatif Tipe Jigsaw terhadap Prestasi Belajar Siswa pada Pelajaran Fisika SMK. Jurnal Pemikiran Penelitian Pendidikan

dan

Sains, 4, 1, 73-77 http://www.journal.uim.ac.i d/index.php/wacanadidaktika/article/view/8 $\underline{0 / 46}$

Imawan, R, . O. (2015). Perbandingan antara Keefektifan Model Guided Discovery Learning dan ProjectBased Learning pada Matakuliah Geometri. $J$ urnal Pendidikan Matematika, 10, 2, 179-188 ht 
tps://iournal.uny.ac.id/index.php/pythagoras /article/view/9156/pdf

Moestofa, M., \& Sondang S., M. (2013). Penerapan Model Pembelajaran Berdasarkan Masalah pada Standar Kompetensi Memperbaiki Radio Penerima di SMK Negeri 3 Surabaya. Jurnal Pendidikan Teknik Elektro, 2 (1):255-261. http://iournal.um.ac.id/index.ph p/iip/article/view/4211

Muslim, S. R. (2017). Pengaruh Penggunaan Model Project Based Learning Terhadap Kemampuan Pemecahan Masalah Matematis Peserta Didik SMA. Supremum Journal of Mathematics Education (SJME),1(2), 88-95. https://iournal.unsika.ac.i d/index.php/supremum/article/view/756/68 $\underline{6}$

Nafi'an, I., M. (2011). Kemampuan Siswa Dalam Menyelesaikan Soal Cerita Ditinjau Dari Gender di Sekolah Dasar. Jurusan Pendidikan Matematika, 6, 3, 978 - 979 https://eprints.unv.ac.id/7413 $11 / \mathrm{p}-53 . \mathrm{pdf}$

Raharjo, B. S. (2012) Evaluasi Trend Kualitas Pendidikan di Indonesia. Jurnal Penelitian dan Evaluasi

Pendidikan, 16, 2, 511-532. https://iournal.un y.ac.id/index.php/ipep/issue/view/202

Rose, A., R. \& Prasetya, T,. A. (2014). Keefektifan Strategi Project Based Learning Berbantuan Modul Pada Hasil Belajar Kimia Siswa. Jurnal Inovasi Pendidikan Kimia $, \quad 8, \quad 2, \quad 1360$ 1369 https://iournal.unnes.ac.id/niu/index.p $\mathrm{hp} / \mathrm{JIPK} /$ article/view/4441

Rosdiana, Boleng, T. D., Susilo. (2017). Pengaruh Penggunaan Model Discovery Learning Terhadap Efektivitadan Hasil Belajar Siswa. Jurnal Pendidikan, 2, 8, 1060-1064 http://iourn al.um.ac.id/index.php/iptpp/article/view/98 $\underline{02 / 4639}$

Romadloniyah, A., \& Setiaji, K. (2020). Pengaruh Status Sosial Ekonomi Orang Tua, Konformitas, Dan Literasi Keuangan Terhadap Perilaku Konsumtif Dalam Prespektif Gender. Economic Education Analysis Journal,

9

(1) 50-64 https://journal.unnes.ac.id/sju/inde x.php/eeai/article/view/37224/15322

Saputra, E. Y. (2016). The Application Of Project Based Learning (Project Based Learning) Model To Imrove Learning Activeness And
Result Study Control System Engeneering In Class XII EI 3 Smk N 3 Wonosari. Jurnal Pendidikan Teknik Elektronika 5,3, 1-6 http://journal.student.uny. ac.id/ois/index.php/elektronika/article/view /2204/1888

Sumianingrum, E. N., Wibawanto, H., \& Haryono. (2017). Efektivitas Metode Discovery Learning Berbantuan E-Learning di SMA Negeri 1 Jepara. Innovative Journal of Curriculum

and Educational Technology, 8(1),1-10

https://iournal.unnes.ac.id/siu/index.php/ui et/article/view/30113

Setyawan, R. B., \& Munoto. (2016). Implementasi Model Pembelajaran Langsung Menggunakan Software AutoCAD Pada Kompetensi Dasar Menggambar Rencana Instalasi Penerangan di SMK Raden Patah Mojokerto. Jurnal Pendidikan Teknik Elektro, 5(3), 951-956. https://jurnalmahasisw a.unesa.ac.id/index.php/iurnal-pendidikanteknik-elektro/article/view/16810/15274

Syafitri, N. (2017). Perbedaan Gaya Belajar Siswa Laki-Laki Dan Perempuan X Jasa Boga Pada Pelajaran Ilmu Gizi di SMKN 6 Yogyakarta. Jurnal

Pendidikan Teknik Boga, 6,7, 1-9 http://iournal. student.unv.ac.id/ojs/ojs/index.php/boga/art icle/view/10213/9777

Saputra, D., H., Ismet, F. \& Andrizal. (2018) Pengaruh Motivasi Terhadap Hasil Belajar Siswa SMK. Jurnal Inovasi Vokasional dan Teknologi. 18,1, 25-30 http://invotek.ppi.unp.ac.id/index.php /invotek/article/view/168

Susilowati, I., Iswari, S. R., \& Sukaesih, S. (2013) Pengaruh Pembelajaran Berbasis Proyek Terhadap Hasil Belajar Siswa Materi Sistem Pencernaan Manusia. Unnes Journal of Biology Education, 2 (1), 83-90 https://iournal unnes.ac.id/sju/index.php/uibe/article/view $\underline{12618}$

Yuwono, R. M., Udiyono, Maárif, H. D., Sulistiana. (2019). Students 'Critical Thinking Profile To Solve The Problem Of Analytical Geometry Viewed From Gender. Al-Jabar: Jurnal Pendidikan Matematika, 10, 1, 37 - 46 http://www.ejournal.radenintan.ac.id/index. php/al-jabar/article/view/3768/2717 